\title{
Isotopomeric characterization of nitrous oxide produced by reaction of enzymes extracted from nitrifying and denitrifying bacteria
}

\author{
T. Yamazaki ${ }^{1, *}$, T. Hozuki ${ }^{2}$, K. Arai ${ }^{2}$, S. Toyoda ${ }^{1}$, K. Koba ${ }^{4}$, T. Fujiwara ${ }^{2}$, and N. Yoshida ${ }^{1,3,5}$ \\ ${ }^{1}$ Department of Environmental Science and Technology, Tokyo Institute of Technology, 4259 Nagatsuta, Midori-ku, \\ Yokohama 226-8502, Japan \\ ${ }^{2}$ Department of Biological Science, Graduate School of Science, Shizuoka University, 836 Oh-ya, Suruga-ku, Shizuoka \\ 422-8529, Japan \\ ${ }^{3}$ Department of Environment Chemistry and Engineering, Tokyo Institute of Technology, 4259 Nagatsuta, Midori-ku, \\ Yokohama 226-8502, Japan \\ ${ }^{4}$ Institute of Agriculture, Tokyo University of Agriculture and Technology, Tokyo University of Agriculture and Technology, \\ 3-5-8 Saiwai-cho, Fuchu-city, Tokyo 183-8509, Japan \\ ${ }^{5}$ Earth-Life Science Institute, Tokyo Institute of Technology, Meguro, Tokyo, 152-8551, Japan \\ * present address: LSI Medience Corporation, 1000 Kamoshita-chou, Aoba-ku, Yokohama 227-0033, Japan
}

Correspondence to: S. Toyoda (toyoda.s.aa@m.titech.ac.jp)

Received: 26 September 2013 - Published in Biogeosciences Discuss.: 25 October 2013

Revised: 29 March 2014 - Accepted: 6 April 2014 - Published: 21 May 2014

\begin{abstract}
Nitrous oxide $\left(\mathrm{N}_{2} \mathrm{O}\right)$ is a potent greenhouse gas and produced in denitrification and nitrification by various microorganisms. Site preference (SP) of ${ }^{15} \mathrm{~N}$ in $\mathrm{N}_{2} \mathrm{O}$, which is defined as the difference in the natural abundance of isotopomers ${ }^{14} \mathrm{~N}^{15} \mathrm{NO}$ and ${ }^{15} \mathrm{~N}^{14} \mathrm{NO}$ relative to ${ }^{14} \mathrm{~N}^{14} \mathrm{NO}$, has been reported to be a useful tool to quantitatively distinguish $\mathrm{N}_{2} \mathrm{O}$ production pathways. To determine representative SP values for each microbial process, we firstly measured SP of $\mathrm{N}_{2} \mathrm{O}$ produced in the enzyme reaction of hydroxylamine oxidoreductase (HAO) purified from two species of ammonia oxidizing bacteria (AOB), Nitrosomonas europaea and $\mathrm{Ni}$ trosococcus oceani, and that of nitric oxide reductase (NOR) from Paracoccus denitrificans. The SP value for NOR reaction $(-5.9 \pm 2.1 \%$ o $)$ showed nearly the same value as that reported for $\mathrm{N}_{2} \mathrm{O}$ produced by $P$. denitrificans in pure culture. In contrast, SP value for HAO reaction $(36.3 \pm 2.3 \%$ ) was a little higher than the values reported for $\mathrm{N}_{2} \mathrm{O}$ produced by AOB in aerobic pure culture. Using the SP values obtained by $\mathrm{HAO}$ and NOR reactions, we calculated relative contribution of the nitrite $\left(\mathrm{NO}_{2}^{-}\right)$reduction (which is followed by $\mathrm{NO}$ reduction) to $\mathrm{N}_{2} \mathrm{O}$ production by $N$. oceani incubated under different $\mathrm{O}_{2}$ availability. Our calculations revealed that previous in vivo studies might have underestimated the SP value for the $\mathrm{NH}_{2} \mathrm{OH}$ oxidation pathway possibly due to a
\end{abstract}

small contribution of $\mathrm{NO}_{2}^{-}$reduction pathway. Further evaluation of isotopomer signatures of $\mathrm{N}_{2} \mathrm{O}$ using common enzymes of other processes related to $\mathrm{N}_{2} \mathrm{O}$ would improve the isotopomer analysis of $\mathrm{N}_{2} \mathrm{O}$ in various environments.

\section{Introduction}

Nitrous oxide $\left(\mathrm{N}_{2} \mathrm{O}\right)$ is a potent greenhouse gas and contributes indirectly to the destruction of the ozone layer in the stratosphere (Ravishankara et al., 2009). Production of $\mathrm{N}_{2} \mathrm{O}$ on earth is mainly controlled by microbial processes that include nitrification and denitrification (Stein and Yung, 2003). In nitrification, autotrophic microorganisms like ammonia oxidizing archaea (AOA) and ammonia oxidizing bacteria (AOB) oxidize ammonia to nitrite $\left(\mathrm{NO}_{2}^{-}\right)$and produce $\mathrm{N}_{2} \mathrm{O}$ as a byproduct under mainly aerobic conditions (Casciotti et al., 2011). However, various heterotrophic denitrifying microorganisms such as archaea, bacteria, and fungi reduce nitrate $\left(\mathrm{NO}_{3}^{-}\right)$or $\mathrm{NO}_{2}^{-}$to dinitrogen $\left(\mathrm{N}_{2}\right)$ as electron acceptors for anaerobic respiration and produce $\mathrm{N}_{2} \mathrm{O}$ as an intermediate under mainly anaerobic conditions (Hayastu et al., 2008). Thus, production and consumption of $\mathrm{N}_{2} \mathrm{O}$ consist of many microbiological functions, including 
autotrophic/heterotrophic and oxic/anoxic processes. Investigation of $\mathrm{N}_{2} \mathrm{O}$ production pathways is useful to understand the nitrogen cycle and relevant microorganisms in various environments.

Natural abundance ratios of isotopomers, a set of molecules containing various stable isotopes, have been used to analyze the $\mathrm{N}_{2} \mathrm{O}$ production pathways, and several studies have reported isotopomer ratios of each $\mathrm{N}_{2} \mathrm{O}$ production pathway using several strains belonging to bacteria, archaea, and fungi (Casciotti et al., 2011; Frame and Casciotti, 2010; Santoro et al., 2011; Sutka et al., 2008, 2006, 2004; Toyoda et al., 2005; Yoshida, 1988). These studies showed that the site preference (SP), which was defined as the difference in ${ }^{15} \mathrm{~N}$ enrichment between the center $(\alpha)$ and the terminal $(\beta)$ $\mathrm{N}$ atoms in $\mathrm{N}_{2} \mathrm{O}$ molecules, is a powerful tool to quantitatively distinguish the production pathways such as bacterial $\mathrm{NO}_{2}^{-}$reduction and bacterial hydroxylamine $\left(\mathrm{NH}_{2} \mathrm{OH}\right)$ oxidation, as the SP value for each production pathway was found to be independent of concentrations or isotope ratios of substrates (Toyoda et al., 2005; Sutka et al., 2003, 2004, 2006). To date, isotope analysis has been applied to $\mathrm{N}_{2} \mathrm{O}$ produced in various ecosystems, including natural and agricultural soils, oceans, rivers, wastewater treatment plants (Goldberg et al., 2010; Koba et al., 2009; Park et al., 2011; Sasaki et al., 2011; Toyoda et al., 2011; Well et al., 2008; Yoshida and Toyoda, 2000). However, as argued by Baggs et al. (2008), the isotopomer signatures were reported for only a few bacterial strains and the variation of the signatures among various species was not fully evaluated. In addition, previous reports on the $\mathrm{SP}$ value of $\mathrm{N}_{2} \mathrm{O}$ produced by $\mathrm{NH}_{2} \mathrm{OH}$ oxidation might have been biased by simultaneous $\mathrm{N}_{2} \mathrm{O}$ production by $\mathrm{NO}_{2}^{-}$reduction, since some AOB have denitrifying enzymes and produce $\mathrm{N}_{2} \mathrm{O}$ by $\mathrm{NO}_{2}^{-}$reduction in addition to $\mathrm{NH}_{2} \mathrm{OH}$ oxidation (Arp et al., 2003). In consideration of this problem, Frame and Casciotti (2010) estimated the SP value of $\mathrm{N}_{2} \mathrm{O}$ produced by $\mathrm{NH}_{2} \mathrm{OH}$ oxidation using the relationship between $\mathrm{SP}$ and oxygen isotope ratios in $\mathrm{N}_{2} \mathrm{O}$ obtained in incubation experiments with Nitrosomonas marina C-113a, a marine ammonia-oxidizing bacterium, under various oxygen concentrations. Clearly, more information on SP produced by other strains should be obtained for the better use of SP and precise estimation of the contribution from each $\mathrm{N}_{2} \mathrm{O}$ production pathway.

In this study, we report the isotopomer ratios of $\mathrm{N}_{2} \mathrm{O}$ produced in vitro using enzymes extracted and purified from two strains of AOB (Nitrosococcus oceani and Nitrosomonas europaea) and one species of denitrifying bacteria (Paracoccus denitrificans). Our experiments have the advantage that isotope effects related to the $\mathrm{N}_{2} \mathrm{O}$ production by enzymes (hydroxylamine oxidoreductase (HAO) in $\mathrm{AOB}$ and nitric oxide reductase (NOR) in denitrifier) can be directly determined and that the effects related to other processes such as diffusion of substrate/product through cell membrane and reactions mediated by other enzymes can be excluded. We also measure isotopomer ratios of $\mathrm{N}_{2} \mathrm{O}$ produced in vivo by $N$. oceani under different oxygen concentrations and estimate the relative contribution of $\mathrm{NH}_{2} \mathrm{OH}$ oxidation and $\mathrm{NO}_{2}^{-}$reduction using the isotopomer signatures obtained in vitro.

\section{Materials and methods}

\subsection{Cultivation of the bacterial strains}

Nitrosococcus oceani strain NS58 was kindly supplied by Dr. H. Urakawa (Florida Gulf Coast University). Phylogenetic and morphological analyses indicated a close systematic relationship of the bacterium with $N$. oceani ATCC19707 (Hozuki et al., 2010). The bacterium was cultivated in the $\left(\mathrm{NH}_{4}\right)_{2} \mathrm{SO}_{4}$-supplemented artificial seawater $\left(37.8 \mathrm{mM} \mathrm{NH}_{4}^{+}\right)$, of which the $\mathrm{pH}$ was buffered to 7.8 by $50 \mathrm{mM}$ MOPS (3-morpholinopropanesulfonic acid) as described in detail in a previous report (Hozuki et al., 2010). The inoculated medium in the conical flask was shaken reciprocally at $120 \mathrm{rpm}$ at $25^{\circ} \mathrm{C}$ in a dark condition. After cultivation for 7-10 days and the concentration of $\mathrm{NO}_{2}^{-}$in the medium had reached $25-30 \mathrm{mM}$, the culture of the bacterium in the late-log or stationary phase was used for the in vivo experiments as described below. Large-scale cultivation of the bacterium to prepare the starting material for purification of $\mathrm{HAO}$ was carried out with the same procedure, but using a glass bottle $10 \mathrm{~L}$ in volume with vigorous air ventilation through a sterilized air filter.

Cultivated cells of Nitrosomonas europaea ATCC19718, which was obtained by large-scale cultivation in accordance to a previous study (Yamanaka and Shinra, 1974), were kindly supplied by Dr. Y. Fukumori (Graduate School of Natural Science and Technology, Kanazawa University) and were used as a starting material for the purification of HAO. Paracoccus denitrificans ATCC 35512 was cultured under denitrifying conditions and used for preparing a purified NOR according to the previous report by Fujiwara and Fukumori (1996).

\subsection{Purification of hydroxylamine oxidoreductase (HAO)}

HAO was purified from the cultivated NS58 cells through three preparative steps, including $\left(\mathrm{NH}_{4}\right)_{2} \mathrm{SO}_{4}$ fractionation, gel-filtration and hydrogen-bonding chromatography according to a previous report (Hozuki et al., 2010). Catalytic activity of HAO was analyzed by spectrophotometrical measurement of the $\mathrm{NH}_{2} \mathrm{OH}$-dependent reduction of potassium ferricyanide as reported previously (Hozuki et al., 2010). Briefly, the purified enzyme was mixed with $1 \mathrm{~mL}$ of the reaction solution containing $0.1 \mathrm{M}$ sodium phosphate buffer ( $\mathrm{pH} 7.8$ ), $20 \mu \mathrm{M} \mathrm{NH} \mathrm{N}_{2} \mathrm{OH}$ and $100 \mu \mathrm{M}$ potassium ferricyanide. Then, the decreasing rate of absorbance at $420 \mathrm{~nm}$ of the solution was monitored using a cuvette with an optical path length of $1 \mathrm{~cm}$ and a spectrophotometer (MPS-2000, Shimadzu, Kyoto, 
Japan). The difference in the millimolar extinction coefficient $\left(\Delta \varepsilon_{\mathrm{mM}}\right)$ at $420 \mathrm{~nm}$ between ferricyanide and ferrocyanide was $1.02 \mathrm{mM}^{-1} \mathrm{~cm}^{-1}$. We obtained $1.8 \mathrm{mg}$ of the purified

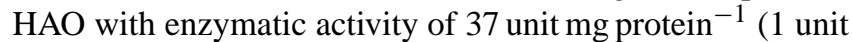
is equivalent to the activity where $1 \mu \mathrm{mol}$ of $\mathrm{NH}_{2} \mathrm{OH}$ is oxidized in a minute) and used it for the assay of $\mathrm{N}_{2} \mathrm{O}$ generating activity. $\mathrm{HAO}$ was also purified from $N$. europaea according to the method of Yamanaka et al. (1979) with some modifications. We found lower catalytic activity for the enzyme purified from $N$. europaea $\left(6.7\right.$ unit $\mathrm{mg}$ protein $\left.^{-1}\right)$; this is probably because we used an old stock of the cultivated bacterial cells which had been kept for about 10 years at $-30{ }^{\circ} \mathrm{C}$.

\subsection{Quantitative and isotopomeric analysis of $\mathrm{N}_{2} \mathrm{O}$ produced during oxidation of $\mathrm{NH}_{2} \mathrm{OH}$ with $\mathrm{HAO}$}

In a $69 \mathrm{~mL}$ glass vial (Maruemu Corp., Osaka, Japan), $10 \mathrm{~mL}$ of substrate solution was prepared so that it contains 0.1$3 \mathrm{mM}$ hydroxylamine, $1 \mathrm{mM}$ potassium ferricyanide as an electron acceptor, and $10 \mathrm{mM}$ sodium phosphate as buffer $(\mathrm{pH}=7.8)$. After the vial was sealed with a butyl rubber stopper and an aluminum cap, air in the headspace was replaced with pure $\mathrm{N}_{2}$ (Shizuoka Sanso Co., Shizuoka, Japan), and then the reaction was started by injecting 0.1 unit of the HAO extracted from N. oceani or N. europaea. Experiments with $3 \mathrm{mM} \mathrm{NH} \mathrm{NH}_{2} \mathrm{OH}$ were conducted on four different dates (A-D). In experiments $\mathrm{C}$ and $\mathrm{D}$, the lot number of $\mathrm{NH}_{2} \mathrm{OH}$ reagent (hydroxylamine hydrochloride, Wako Pure Chemical Industries, Ltd., Osaka, Japan) was different from that used in experiments A and B. After incubating the vial for $2 \mathrm{~h}$ at $25^{\circ} \mathrm{C}$ or for $12 \mathrm{~h}$ on ice, gas samples were extracted and analyzed as described below. Concentration of $\mathrm{NO}_{2}^{-}$was determined spectrophotometrically by a diazo-coupling method (Nicholas and Mason 1957).

\subsection{Purification of nitric oxide reductase (NOR) from Paracoccus denitrificans}

NorBC-type NO reductase was purified from the cultivated $P$. denitrificans cells according to a previous report (Fujiwara and Fukumori 1996) with some modification. The membrane fraction was prepared from the bacterial cells that had been cultivated anaerobically in the presence of $\mathrm{NO}_{3}^{-}$. NO reductase was extracted from the membrane fraction by treating with the $1 \%(w / v) 3$-[(3-cholamidopropyl)dimethylammonio]1-propanesulfonate (CHAPS; Dojindo Lab., Kumamoto, Japan). It was then fractionated by anion-exchange chromatography using DEAE-Toyopearl $650 \mathrm{M}$ gel (Tosoh, Tokyo, Japan).

NO-reducing activity of the purified enzyme was measured spectrometrically by monitoring NO-dependent oxidation of horse ferrocytochrome $c$ (Nacalai Tesque, Kyoto, Japan). Experimental procedure was detailed in a pre- vious report (Fujiwara and Fukumori 1996). Before starting the assay of NO-reducing activity, dissolved oxygen in the solution was enzymatically removed using D-glucose oxidase/catalase system in order to prevent its reaction with NO. A stock solution of NO-saturated ethanol $(11.9 \mathrm{mM})$ was prepared by purging ethanol with pure NO gas (Sumitomo Seika Chemicals Co., Ltd. Osaka, Japan) (Seidell and Linke, 1965). Oxidation rate of ferrocytochrome $c$ was measured by monitoring the decrease in the absorbance at $550 \mathrm{~nm}$ with a spectrophotometer (MPS-2000, Shimadzu, Kyoto, Japan), whereby the difference in millimolar extinction coefficient $\left(\Delta \varepsilon_{\mathrm{mM}}, 21.0 \mathrm{mM}^{-1} \mathrm{~cm}^{-1}\right)$ at $550 \mathrm{~nm}$ between the reduced and oxidized form of horse ferro- and ferricytochrome $c$ was used. NO-reducing activity of the purified enzyme was estimated to be 35 unit mg protein ${ }^{-1}$ (1 unit is equivalent to the activity where $1 \mu \mathrm{mol}$ of $\mathrm{NO}$ is reduced in a minute).

\subsection{Isotopomeric analysis of $\mathrm{N}_{2} \mathrm{O}$ produced by enzymatic reduction of $\mathrm{NO}$}

In the same glass vial that had been used for $\mathrm{NH}_{2} \mathrm{OH}$ oxidation experiments, a $10 \mathrm{~mL}$ solution was prepared so that it contained $10 \mathrm{mM}$ sodium phosphate buffer ( $\mathrm{pH} 6.0), 2.9 \mu \mathrm{M}$ horse cytochrome $c, 1.0 \mathrm{mM}$ sodium ascorbate and $0.1 \mathrm{mM}$ $\mathrm{N}, \mathrm{N}, \mathrm{N}^{\prime}, \mathrm{N}^{\prime}$-tetramethyl-p-phenylenediamine (TMPD). The reaction was started by injecting the NO-saturated ethanol to yield final concentration of $50 \mu \mathrm{M}$, and the purified NO reductase ( 0.005 unit) by using a gastight syringe (VICI Precision Sampling Inc., Baton Rouge, LA). Experiments were conducted on three different dates (A, C, and D). After incubating the vial for $2 \mathrm{~h}$ at $25^{\circ} \mathrm{C}$ or for $12 \mathrm{~h}$ on ice, the gas phase in the headspace of the reaction vial was extracted and the isotopomeric analysis of the produced $\mathrm{N}_{2} \mathrm{O}$ was conducted as mentioned below.

\subsection{Quantitative and isotopomeric analysis of $\mathrm{N}_{2} \mathrm{O}$ produced from cultivated $N$. oceani cells}

The $70 \mathrm{~mL}$ culture of the $N$. oceani NS58 was centrifuged at $9800 \mathrm{~g}$ for $60 \mathrm{~min}$ at $4{ }^{\circ} \mathrm{C}$ (refrigerated centrifugator model 3700, Kubota Corp., Tokyo, Japan). Obtained pelleted cells were suspended in the $70 \mathrm{~mL}$ of the pH-buffered and $\left(\mathrm{NH}_{4}\right)_{2} \mathrm{SO}_{4}$-supplemented artificial seawater (see Sect. 2.1), then were incubated with gentle stirring at $25^{\circ} \mathrm{C}$ in dark for 30 min to remove $\mathrm{NO}_{2}^{-}$that accumulate in the medium during the cultivation. The resulting cell suspension was centrifuged again under the same condition, and the cell pellet was resuspended in the same volume of the freshly prepared culture medium and used as the washed cell suspension.

Reaction solution was prepared in a glass vial by mixing $1.0 \mathrm{~mL}$ of the washed cell suspension and $9.0 \mathrm{~mL}$ of the cultivation medium. Cell density of the medium in the reaction vial was estimated at $5.8 \times 10^{6}$ cells $\mathrm{mL}^{-1}$ by direct counting of the fixed and 4',6-diamidino-2-phenylindole (DAPI)stained cells using an epifluorescent microscope according to 
Takenaka et al. (2007). After sealing, the headspace $(59 \mathrm{~mL}$ in volume) of the vial was replaced with a pure $\mathrm{N}_{2}$ or $\mathrm{O}_{2} / \mathrm{N}_{2}$ mixture that contained $2 \%(v / v) \mathrm{O}_{2}$ (Shizuoka Sanso Co., Shizuoka, Japan) by gently bubbling for $15 \mathrm{~min}$. In addition to the anaerobic $\left(0 \% \mathrm{O}_{2}\right)$ and the microaerobic $(2 \%$ $\mathrm{O}_{2}$ ) vials, an aerobic vial without gas replacement was prepared. Incubation of the bacterial cells in the vials was carried out by gentle shaking at $25^{\circ} \mathrm{C}$ in dark. After 24 or $48 \mathrm{~h}$ from starting the incubation, $50 \mu \mathrm{M}$ of $10 \mathrm{M} \mathrm{NaOH}$ solution was added into the vials to stop the microbial reaction. Quantification and measurement of isotopomer ratios of $\mathrm{N}_{2} \mathrm{O}$ gas released into the headspace of the incubation vial were performed as described below. Concentration of accumulated $\mathrm{NO}_{2}^{-}$was also measured as described above.

\subsection{Measurement of $\mathrm{N}_{2} \mathrm{O}$ concentration and isotopomer ratios}

Concentrations and isotopomer ratios of $\mathrm{N}_{2} \mathrm{O}$ were measured using an online analytical system that originally was developed for $\mathrm{N}_{2} \mathrm{O}$ dissolved in water samples (Toyoda et al., 2002). The system consists of a gas extraction chamber with a septum for syringe injection, traps made of stainless steel tubing or glass, a gas chromatograph (Agilent 6890, Agilent Technologies Japan, Ltd., Tokyo) and an isotope-ratio monitoring mass spectrometer (MAT 252, ThermoFisher Scientific KK, Yokohama) equipped with GC interface.

Using a gastight syringe, 0.1 to $1.5 \mathrm{~mL}$ of the gas was extracted from the headspace of the sample vial and was injected into the gas extraction chamber. The sample gas was then transferred by $\mathrm{He}$ carrier gas to chemical traps $\left(\mathrm{Mg}\left(\mathrm{ClO}_{4}\right)_{2}\right.$ and $\mathrm{NaOH}$ on support) to remove $\mathrm{H}_{2} \mathrm{O}$ and $\mathrm{CO}_{2}$, and $\mathrm{N}_{2} \mathrm{O}$ was concentrated on glass beads packed in a $\mathrm{U}$-shaped trap at liquid $\mathrm{N}_{2}$ temperature. After further purification on $\mathrm{GC}, \mathrm{N}_{2} \mathrm{O}$ was introduced into the mass spectrometer for isotope ratio monitoring. Site-specific nitrogen isotope analysis was conducted with ion detectors modified for mass analysis of fragment ions of $\mathrm{N}_{2} \mathrm{O}\left(\mathrm{NO}^{+}\right)$that contain an $\mathrm{N}$ atom in the center position of the $\mathrm{N}_{2} \mathrm{O}$ molecules (Toyoda and Yoshida, 1999). Concentration and bulk nitrogen and oxygen isotope ratio of $\mathrm{N}_{2} \mathrm{O}$ was determined by analysis of $\mathrm{N}_{2} \mathrm{O}$ molecule ions $\left(\mathrm{N}_{2} \mathrm{O}^{+}\right)$. Pure $\mathrm{N}_{2} \mathrm{O}$ was used as a reference gas for isotopomer ratios. Notation of isotopomer ratios of $\mathrm{N}_{2} \mathrm{O}$ is shown below.

$\delta^{15} \mathrm{~N}_{\text {sample }}^{i}={ }^{15} \mathrm{R}_{\text {sample }}^{i} /{ }^{15} \mathrm{R}_{\text {standard }}-1$

$\delta^{18} \mathrm{O}_{\text {sample }}={ }^{18} \mathrm{R}_{\text {sample }} /{ }^{18} \mathrm{R}_{\text {standard }}-1$

In Eqs. (1) and (2), ${ }^{15} \mathrm{R}$ and ${ }^{18} \mathrm{R}$ represent ${ }^{15} \mathrm{~N} /{ }^{14} \mathrm{~N}$ ratio and ${ }^{18} \mathrm{O} /{ }^{16} \mathrm{O}$ ratio, respectively. Subscript "sample" and "standard" indicate isotope ratios for sample and the standard (atmospheric $\mathrm{N}_{2}$ for nitrogen and Vienna Standard Mean Ocean Water (VSMOW) for oxygen), respectively. Superscript $i$ is $\alpha, \beta$, or bulk, which respectively designates central, peripheral, or average isotope ratios in nitrogen atom(s) in $\mathrm{N}_{2} \mathrm{O}$ molecules. We also define the ${ }^{15} \mathrm{~N}$ site preference (SP) as an illustrative parameter of intramolecular distribution of ${ }^{15} \mathrm{~N}$ (Yoshida and Toyoda, 1999). The precision of measurement is better than $0.5 \%$ for $\delta^{15} \mathrm{~N}^{\text {bulk }}$ and $\delta^{18} \mathrm{O}$, and better than $1.0 \%$ for $\delta^{15} \mathrm{~N}^{\alpha}$ and $\delta^{15} \mathrm{~N}^{\beta}$.

${ }^{15} \mathrm{~N}-$ Site preference $(\mathrm{SP})=\delta^{15} \mathrm{~N}^{\alpha}-\delta^{15} \mathrm{~N}^{\beta}$

The $\delta^{15} \mathrm{~N}$ of $\mathrm{NH}_{2} \mathrm{OH}$ was measured using an elemental analyzer coupled with isotope ratio mass spectrometer. Statistical analysis was performed using Excel 2011 (Microsoft, USA). The statistical difference was determined by a twosided Student's $t$ test. A difference of $p<0.05$ was considered significant.

\section{Results}

\subsection{Concentrations and isotopomer ratios of $\mathrm{N}_{2} \mathrm{O}$ produced during oxidation of $\mathrm{NH}_{2} \mathrm{OH}$ with $\mathrm{HAO}$}

The purity of HAO obtained from N. oceani NS58 was confirmed by the SDS-PAGE technique. As shown in Supplement Fig. S1, SDS-PAGE results of the purified sample revealed a single protein band with a molecular weight of approximately 182000 , following pretreatment with SDS (Lane 2). Upon treatment of the enzyme with both SDS and $\beta$-mercaptoethanol, the major band accompanied by minor protein bands with molecular weights of 140000 and 60000 appeared on the gel (Lane 1). The chemical cleavage of the thioester bond between heme $\mathrm{c}$ and a Cys residue in HAO resulted in the appearance of a protein band of molecular weight 60000 (Lane 3), suggesting that the enzyme is composed of a homotrimer of subunit proteins covalently linked together and mediated by prosthetic heme c molecules, as previously reported for N. europaea HAO (Terry and Hooper, 1981; Igarashi et al., 1997). The two minor protein bands observed in Lane 1 possibly correspond to the monomeric and dimeric configurations of the $\mathrm{HAO}$ subunit. In general, $\mathrm{AOB}$ possesses two types of hydroxylamine-oxidizing enzymes: $\mathrm{HAO}$, with a trimeric configuration of the octaheme $\mathrm{c}$ subunit and cytochrome $\mathrm{P} 460$, a monoheme protein with a molecular weight of only approximately 18000 (Numata et al. 1990). Gel filtration was used for purification of $N$. oceani NS58 $\mathrm{HAO}$; thus, contamination of the cytochrome P460 in the enzyme preparation should be improbable. Results of electrophoretic analysis are consistent with the absence of components that may interfere with the correct interpretation of our experimental findings (Lanes 1 and 2, Fig. S1).

Figure 1 shows the amount of $\mathrm{NO}_{2}^{-}$and $\mathrm{N}_{2} \mathrm{O}$ produced during the reaction catalyzed by $\mathrm{HAO}$ from $N$. oceani with different initial concentration of $\mathrm{NH}_{2} \mathrm{OH}(0.1-3 \mathrm{mM})$. About $5.1-29.0 \%$ of $\mathrm{NH}_{2} \mathrm{OH}$ was converted to $\mathrm{NO}_{2}^{-}$or $\mathrm{N}_{2} \mathrm{O}$ after the reaction, and the ratio of produced $\mathrm{NO}_{2}^{-}$and $\mathrm{N}_{2} \mathrm{O}$ decreased with initial $\mathrm{NH}_{2} \mathrm{OH}$ concentration. Production of $\mathrm{N}_{2} \mathrm{O}$ in the blank runs with 1 and $3 \mathrm{mM} \mathrm{NH}_{2} \mathrm{OH}$ were 5.9 


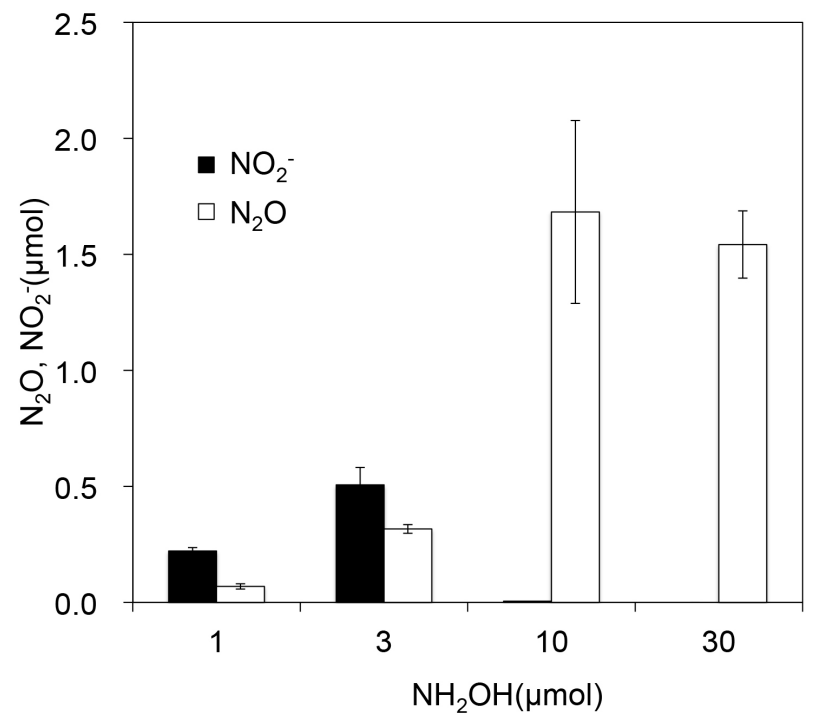

Figure 1. Amounts of $\mathrm{N}_{2} \mathrm{O}$ and $\mathrm{NO}_{2}^{-}$produced by $\mathrm{HAO}$ extracted from $N$. oceani under different substrate $\left(\mathrm{NH}_{2} \mathrm{OH}\right)$ concentration (expressed as amount in the reaction vessel). The error bar indicates standard deviation for three replicates.

and $7.1 \%$ of that in the presence of HAO (HAO+), respectively (Table 1). With lower $\mathrm{NH}_{2} \mathrm{OH}$ concentrations of 0.1 and $0.3 \mathrm{mM}$, however, production of $\mathrm{N}_{2} \mathrm{O}$ in the blank runs was 32.2 and $179.1 \%$ of that observed in the HAO+ runs, respectively (Table 1). For this reason, further experiments were conducted at an initial $\mathrm{NH}_{2} \mathrm{OH}$ concentration of $3 \mathrm{mM}$ to examine repeatability of the reaction and effect of bacterial strain and $\mathrm{N}$ isotope ratio of $\mathrm{NH}_{2} \mathrm{OH}$. The $\delta^{15} \mathrm{~N}^{\text {bulk }}$ and $\delta^{18} \mathrm{O}$ of $\mathrm{N}_{2} \mathrm{O}$ showed lower values at high $(3 \mathrm{mM}) \mathrm{NH}_{2} \mathrm{OH}$ concentration compared to low (1 mM) concentration (Table 1). SP value was independent of substrate concentration or the degree of the reaction, since the difference in SP values between experiments with 1 and $3 \mathrm{mM} \mathrm{NH}_{2} \mathrm{OH}$ was insignificant $(p>0.05)$.

Results obtained with an initial $\mathrm{NH}_{2} \mathrm{OH}$ concentration of $3 \mathrm{mM}$ showed that $\delta^{15} \mathrm{~N}^{\text {bulk }}$ of $\mathrm{N}_{2} \mathrm{O}$ produced by $N$. oceani (experiments $\mathrm{A}$ and $\mathrm{B}$ ) and $N$. europaea (experiment A) was almost constant and about $10 \%$ lower than $\delta^{15} \mathrm{~N}$ of $\mathrm{NH}_{2} \mathrm{OH}$ $\left(-7.0 \%\right.$ ) (Table 2). Similar $\delta^{15} \mathrm{~N}$ difference $(9 \%$ ) between $\mathrm{N}_{2} \mathrm{O}$ and $\mathrm{NH}_{2} \mathrm{OH}$ was observed in experiment $\mathrm{D}$, in which $\mathrm{NH}_{2} \mathrm{OH}$ with lower $\delta^{15} \mathrm{~N}$ value $(-43.9 \%$ o) was used. In experiment $\mathrm{C}$ of both $\mathrm{N}$. europaea and $\mathrm{N}$. oceani, however, $\delta^{15} \mathrm{~N}$ of $\mathrm{N}_{2} \mathrm{O}$ was higher than that of $\mathrm{NH}_{2} \mathrm{OH}$ by $1.8-9.9 \%$ o (Table 2). The $\delta^{18} \mathrm{O}$ also showed a variation among experiments A-D of $N$. oceani, although it is not clear whether the $\delta^{18} \mathrm{O}$ of $\mathrm{NH}_{2} \mathrm{OH}$ was different between experiments $\mathrm{A} / \mathrm{B}$ and $\mathrm{C} / \mathrm{D}$. When we compare the results from experiment $\mathrm{A}$, the $\delta^{15} \mathrm{~N}^{\text {bulk }}$ and $\delta^{18} \mathrm{O}$ of $\mathrm{N}_{2} \mathrm{O}$ were not significantly different between the two strains.
In contrast, the $\mathrm{SP}$ value of $\mathrm{N}_{2} \mathrm{O}$ produced by $\mathrm{NH}_{2} \mathrm{OH}$ oxidation with $\mathrm{HAO}$ was independent of initial concentration and $\delta^{15} \mathrm{~N}$ value of $\mathrm{NH}_{2} \mathrm{OH}$ or degree of reaction process ( $\mathrm{Ta}-$ bles 1 and 2). Moreover, the difference in SP between experiments with $\mathrm{HAO}$ extracted from $N$. oceani in experiments A, $\mathrm{B}, \mathrm{C}$ and D (average: $36.2 \pm 1.7 \%$ o, $n=7$ ) and $N$. europaea in experiments $\mathrm{A}$ and $\mathrm{C}$ (average: $36.6 \pm 3.3 \%, n=4$ ) was insignificant $(p>0.05)$.

\subsection{Concentration and isotopomer ratios of $\mathrm{N}_{2} \mathrm{O}$ produced during reduction of NO with NOR}

Table 3 shows concentration and isotopomer ratios of $\mathrm{N}_{2} \mathrm{O}$ produced by the reduction of NO with NOR. About 65.0 $149.2 \%$ of $\mathrm{NO}$ was converted to $\mathrm{N}_{2} \mathrm{O}$. The concentration of $\mathrm{N}_{2} \mathrm{O}$ was 17 times and 7.3 times higher in the presence of NOR (NOR+) compared to the blank runs without NOR. $\mathrm{SP}$ values of $\mathrm{N}_{2} \mathrm{O}$ from the enzymatic reaction showed little variation $(-5.9 \pm 2.1 \%$ ) and were lower than SP values observed in the control runs $(15.1-16.8 \%)(p<0.05)$.

\subsection{Isotopomer ratio of $\mathrm{N}_{2} \mathrm{O}$ produced by $N$. oceani under different initial $\mathrm{O}_{2}$ concentration}

The amount of $\mathrm{N}_{2} \mathrm{O}$ produced by $N$. oceani was $2.9 \pm 0.9$ $(n=6), 8.9 \pm 0.5(n=2)$, and $18.1 \pm 3.6(n=5) \mathrm{nmol}$ for $\mathrm{O}_{2}$ concentrations of 0,2 , and $21 \%$, respectively. Production of both $\mathrm{N}_{2} \mathrm{O}$ and $\mathrm{NO}_{2}^{-}$was much higher under aerobic conditions than under anaerobic conditions $(p<0.05$, Fig. 2$)$. Isotopomer ratios of $\mathrm{N}_{2} \mathrm{O}$ showed a strong dependence on initial $\mathrm{O}_{2}$ concentration (Fig. 3). They were more enriched under aerobic conditions compared to anaerobic conditions, and positive correlation between the isotopomer ratios was observed (Fig. 3, $R^{2}=0.89, p<0.05$ ).

\section{Discussion}

The characteristic SP value of $\mathrm{N}_{2} \mathrm{O}$ produced during the in vitro oxidation of $\mathrm{NH}_{2} \mathrm{OH}$ with $\mathrm{HAO}$ from the two strains of AOB $(36.3 \pm 2.3 \%$ o indicates that this parameter is determined by the enzymatic reaction step and is not affected by other factors such as concentration, the extent of reaction, and nitrogen isotope ratios of substrate (Table 2). This study demonstrates the first direct evidence of isotopomeric fractionation of $\mathrm{N}_{2} \mathrm{O}$ produced by enzymatic reactions, confirming the robustness of $\mathrm{SP}$ of $\mathrm{N}_{2} \mathrm{O}$ as predicted by previous studies (e.g., Frame and Casciotti. 2010).

Observed dependence of product $\mathrm{NO}_{2}^{-} / \mathrm{N}_{2} \mathrm{O}$ ratio on initial $\mathrm{NH}_{2} \mathrm{OH}$ concentration could be caused by the availability of electron acceptors. The oxidation of $\mathrm{NH}_{2} \mathrm{OH}$ with $\mathrm{HAO}$ mainly provides $\mathrm{NO}_{2}^{-}$as a product when enough electron acceptors are supplied, while the reaction is likely to produce $\mathrm{N}_{2} \mathrm{O}$ when the amount of electron acceptors is not enough to complete the reaction as proposed by Yamanaka and Sakano (1980). In the present study, electron acceptors (potassium 
Table 1. Concentration and isotopomer ratios of $\mathrm{N}_{2} \mathrm{O}$ produced during $\mathrm{NH}_{2} \mathrm{OH}$ oxidation by $\mathrm{HAO}$ enzyme extracted from $\mathrm{N}$. oceani with different concentrations of $\mathrm{NH}_{2} \mathrm{OH}$.

\begin{tabular}{lrrrrrrrrr}
\hline HAO & $\mathrm{NH}_{2} \mathrm{OH}$ & & $\begin{array}{r}\text { Concentration } \\
\left(\mu \mathrm{mol} \mathrm{L} \mathrm{L}^{-1}\right)\end{array}$ & $\begin{array}{r}\text { Yield } \\
(\%)\end{array}$ & $\begin{array}{r}\delta^{15} \mathrm{~N}^{\text {bulk }} \\
(\% \circ)\end{array}$ & $\begin{array}{r}\delta^{15} \mathrm{~N}^{\alpha} \\
(\% \circ)\end{array}$ & $\begin{array}{r}\delta^{15} \mathrm{~N}^{\beta} \\
(\%)\end{array}$ & $\begin{array}{r}\delta^{18} \mathrm{O} \\
(\% o)\end{array}$ & $\begin{array}{r}\mathrm{SP} \\
(\% o)\end{array}$ \\
\hline+ & $3 \mathrm{mM}$ & Average $\pm \mathrm{SD}$ & $23.9 \pm 2.2$ & $5.1 \pm 0.4$ & $-17.9 \pm 0.2$ & $0.1 \pm 0.2$ & $-36.0 \pm 0.2$ & $37.8 \pm 0.1$ & $36.1 \pm 0.2$ \\
Blank & $3 \mathrm{mM}$ & & 1.7 & 0.4 & -17.0 & -2.9 & -31.1 & 32.3 & 28.2 \\
+ & $1 \mathrm{mM}$ & Average $\pm \mathrm{SD}$ & $26.1 \pm 6.1$ & $16.8 \pm 3.9$ & $-13.4 \pm 0.2$ & $4.7 \pm 0.4$ & $-31.6 \pm 0.3$ & $42.6 \pm 0.2$ & $36.3 \pm 0.6$ \\
Blank & $1 \mathrm{mM}$ & & 1.5 & 1.0 & -15.4 & 1.0 & -31.8 & 37.7 & 32.8 \\
+ & $0.3 \mathrm{mM}$ & Average $\pm \mathrm{SD}$ & $4.9 \pm 0.3$ & $10.6 \pm 0.3$ & $-5.8 \pm 0.2$ & $12.0 \pm 0.3$ & $-23.6 \pm 0.2$ & $44.5 \pm 0.1$ & $35.6 \pm 0.3$ \\
Blank & $0.3 \mathrm{mM}$ & & 1.6 & 3.4 & -15.1 & 2.9 & -33.1 & 47.7 & 36.0 \\
+ & $0.1 \mathrm{mM}$ & Average $\pm \mathrm{SD}$ & $1.1 \pm 0.2$ & $6.9 \pm 1.2$ & $-10.7 \pm 0.5$ & $6.6 \pm 0.4$ & $-28.1 \pm 0.4$ & $45.1 \pm 0.8$ & $34.7 \pm 0.9$ \\
Blank & $0.1 \mathrm{mM}$ & & 1.9 & 12.3 & -15.5 & 0.5 & -31.5 & 50.4 & 32.0 \\
\hline
\end{tabular}

Concentration is that in the gas phase (head space) in the vial. $\mathrm{N}_{2} \mathrm{O}$ yield represents the fraction of $\mathrm{N}$ atoms converted to $\mathrm{N}_{2} \mathrm{O}$ from substrate $\mathrm{NH} \mathrm{H}_{2} \mathrm{OH}$ ([ $\left.\mathrm{N}_{2} \mathrm{O}-\mathrm{N}\right] /\left[\mathrm{NH}_{2} \mathrm{OH}-\mathrm{N}\right]$ ). Isotopomer ratios for "HAO+" were corrected for the blank. Average and SD (standard deviation) were calculated for samples, including HAO in each condition $(n=3)$.

Table 2. Concentration and isotopomer ratios of $\mathrm{N}_{2} \mathrm{O}$ produced during $\mathrm{NH}_{2} \mathrm{OH}$ oxidation by $\mathrm{HAO}$ enzyme extracted from Nitrosococcus oceani and Nitrosomonas europaea with $3 \mathrm{mM}$ of $\mathrm{NH}_{2} \mathrm{OH}$.

\begin{tabular}{|c|c|c|c|c|c|c|c|c|}
\hline Experiment & HAO & $\begin{array}{l}\text { Concentration } \\
\qquad\left(\mu \mathrm{mol} \mathrm{L}^{-1}\right)\end{array}$ & $\begin{array}{r}\text { Yield } \\
(\%)\end{array}$ & $\begin{array}{r}\delta^{15} \mathrm{~N}^{\text {bulk }} \\
(\% o)\end{array}$ & $\begin{array}{r}\delta^{15} \mathrm{~N}^{\alpha} \\
(\% o)\end{array}$ & $\begin{array}{r}\delta^{15} \mathrm{~N}^{\beta} \\
(\% o)\end{array}$ & $\begin{array}{r}\delta^{18} \mathrm{O} \\
(\% o)\end{array}$ & $\begin{array}{r}\mathrm{SP} \\
(\% o)\end{array}$ \\
\hline \multicolumn{9}{|c|}{ Nitrosococcus oceani (HAO) } \\
\hline $\mathrm{A}$ & + & 31.0 & 13.3 & -16.5 & 2.1 & -35.1 & 41.6 & 37.1 \\
\hline A & + & 28.1 & 12.1 & -17.1 & 1.8 & -36.0 & 41.3 & 37.8 \\
\hline Average & & $29.6 \pm 2.1$ & $12.7 \pm 0.9$ & $-16.8 \pm 0.4$ & $1.9 \pm 0.2$ & $-35.5 \pm 0.6$ & $41.5 \pm 0.2$ & $37.4 \pm 0.5$ \\
\hline A & Blank & 4.7 & 2.0 & -14.8 & -4.0 & -25.6 & 36.3 & 21.6 \\
\hline B & + & 25.0 & 10.7 & -17.7 & 0.0 & -35.4 & 37.2 & 35.3 \\
\hline B & + & 21.4 & 9.2 & -18.0 & 0.0 & -16.4 & 37.6 & 35.8 \\
\hline B & + & 25.5 & 10.9 & -18.1 & -0.2 & -16.5 & 37.3 & 35.5 \\
\hline Average & & $23.9 \pm 2.2$ & $10.3 \pm 1.0$ & $-17.9 \pm 0.2$ & $-0.1 \pm 0.1$ & $-35.7 \pm 0.2$ & $37.4 \pm 0.2$ & $35.6 \pm 0.3$ \\
\hline B & Blank & 1.7 & 0.7 & -17.0 & -2.9 & -31.1 & 32.3 & 28.2 \\
\hline $\mathrm{C}$ & + & 38.7 & 16.6 & -42.1 & -25.4 & -58.8 & 33.9 & 33.3 \\
\hline $\mathrm{C}$ & Blank & 0.6 & 0.3 & -39.7 & -24.2 & -55.2 & 33.1 & 31.1 \\
\hline $\mathrm{D}$ & + & 24.7 & 10.6 & -52.7 & -33.5 & -71.9 & 56.8 & 38.4 \\
\hline $\mathrm{D}$ & Blank & 2.6 & 1.1 & -49.4 & -38.2 & -60.5 & 54.7 & 22.3 \\
\hline $\mathrm{D}$ & Blank & 0.1 & 0.03 & -46.2 & -27.0 & -65.5 & 55.3 & 38.5 \\
\hline \multicolumn{9}{|c|}{ Nitrosomonas europaea (HAO) } \\
\hline A & + & 32.8 & 14.1 & -14.4 & 4.9 & -33.7 & 42.5 & 38.6 \\
\hline A & + & 36.4 & 15.6 & -13.8 & 4.6 & -32.2 & 42.9 & 36.8 \\
\hline A & + & 34.7 & 14.9 & -17.1 & 2.4 & -36.5 & 42.8 & 38.9 \\
\hline Average & & $34.6 \pm 1.8$ & $14.9 \pm 0.9$ & $-15.0 \pm 1.5$ & $2.9 \pm 1.2$ & $-33.0 \pm 1.9$ & $41.8 \pm 0.2$ & $35.9 \pm 0.9$ \\
\hline A & Blank & 4.7 & 2.0 & -14.8 & -4.0 & -25.6 & 36.3 & 21.6 \\
\hline $\mathrm{C}$ & + & 5.0 & 2.2 & -34.0 & -18.1 & -49.9 & 37.4 & 31.8 \\
\hline $\mathrm{C}$ & Blank & 0.3 & 0.1 & -39.7 & -24.2 & -55.2 & 33.1 & 31.1 \\
\hline
\end{tabular}

Experiments A, B, C and D were conducted on different dates. The initial $\delta^{15} \mathrm{~N}$ value of $\mathrm{NH}_{2} \mathrm{OH}$ was $-7.0 \%$ for $\mathrm{A}$ and $\mathrm{B},-43.9 \%$ for $\mathrm{C}$ and $\mathrm{D}$. Concentration is that in the gas phase (head space) in the vial. $\mathrm{N}_{2} \mathrm{O}$ yield represents the fraction of $\mathrm{N}$ atoms converted to $\mathrm{N}_{2} \mathrm{O}$ from substrate $\mathrm{NH} \mathrm{H}_{2} \mathrm{OH}\left(\left[\mathrm{N}_{2} \mathrm{O}-\mathrm{N}\right] /\left[\mathrm{NH}{ }_{2} \mathrm{OH}-\mathrm{N}\right]\right.$ ). Isotopomer ratios for "HAO+" were corrected for the blank. Average and standard deviation were calculated for samples, including HAO.

ferricyanide) might have been depleted under conditions of 1 and $3 \mathrm{mMNH}_{2} \mathrm{OH}$ because its initial concentration was kept constant. With lower $\mathrm{NH}_{2} \mathrm{OH}$ concentrations $(0.1$ and $0.3 \mathrm{mM}$ ), the production rate of $\mathrm{N}_{2} \mathrm{O}$ was smaller than that of $\mathrm{NO}_{2}^{-}$, and the amount of produced $\mathrm{N}_{2} \mathrm{O}$ became closer to that produced in the blank experiments. The amount of blank $\mathrm{N}_{2} \mathrm{O}$ was almost constant $(70-90 \mathrm{nmol}$; note that the "yield" listed in Table 1 shows the amount of $\mathrm{N}_{2} \mathrm{O}-\mathrm{N}$ relative 
Table 3. Concentration and isotopomer ratios of $\mathrm{N}_{2} \mathrm{O}$ during $\mathrm{NO}$ reduction by NOR extracted from Paracoccus denitrificans.

\begin{tabular}{lcrrrrrrr}
\hline & NOR & $\begin{array}{r}\text { Concentration } \\
\left(\mu \mathrm{mol} \mathrm{L} \mathrm{L}^{-1}\right)\end{array}$ & $\begin{array}{r}\text { Yield } \\
(\%)\end{array}$ & $\begin{array}{r}15 \mathrm{~N}^{\text {bulk }} \\
(\% \circ)\end{array}$ & $\begin{array}{r}15 \mathrm{~N}^{\alpha} \\
(\% \circ)\end{array}$ & $\begin{array}{r}15 \mathrm{~N}^{\beta} \\
(\% \circ)\end{array}$ & $\begin{array}{r}18 \mathrm{O} \\
(\%)\end{array}$ & $\begin{array}{r}\mathrm{SP} \\
(\% \circ)\end{array}$ \\
\hline $\mathrm{A}$ & + & 5.1 & 129.4 & 17.1 & 14.3 & 19.9 & 24.0 & -5.7 \\
$\mathrm{~A}$ & + & 5.0 & 127.9 & 17.1 & 15.1 & 19.1 & 24.1 & -4.0 \\
$\mathrm{~A}$ & + & 5.9 & 149.2 & 17.1 & 14.6 & 19.6 & 22.9 & -5.0 \\
$\mathrm{~A}$ & Blank & 0.3 & 7.6 & 14.5 & 22.0 & 6.9 & -7.5 & 15.1 \\
\hline $\mathrm{C}$ & + & 2.6 & 65.0 & 11.0 & 6.5 & 15.5 & 18.7 & -9.0 \\
$\mathrm{C}$ & Blank & 0.3 & 7.4 & 11.7 & 19.9 & 3.5 & 13.5 & 16.4 \\
$\mathrm{D}$ & Blank & 0.4 & 8.9 & 16.3 & 24.7 & 8.0 & -6.5 & 16.8 \\
\hline Average & & $4.6 \pm 1.4$ & $117.9 \pm 36.5$ & $15.6 \pm 3.0$ & $12.6 \pm 4.1$ & $18.5 \pm 2.1$ & $22.4 \pm 2.5$ & $-5.9 \pm 2.1$ \\
\hline
\end{tabular}

Experiments A, C and D were conducted on different dates. Concentration is that in the gas phase (head space) in the vial. $\mathrm{N}_{2} \mathrm{O}$ yield represents the fraction of $\mathrm{N}$ atoms converted to $\mathrm{N}_{2} \mathrm{O}$ from substrate $\mathrm{NO}\left(\left[\mathrm{N}_{2} \mathrm{O}-\mathrm{N} / \mathrm{NO}-\mathrm{N}\right]\right)$. Isotopomer ratios for $\mathrm{NOR}+$ were corrected for the blank and were averaged for each experiment. SD represents standard deviation for each experiment. For experiment $\mathrm{C}$, results of experiment $\mathrm{D}$ were adopted as the blank, because the blank $\delta^{18} \mathrm{O}$ value obtained in experiment $\mathrm{C}$ was significantly different from that obtained in experiments $\mathrm{A}$ and $\mathrm{D}$.

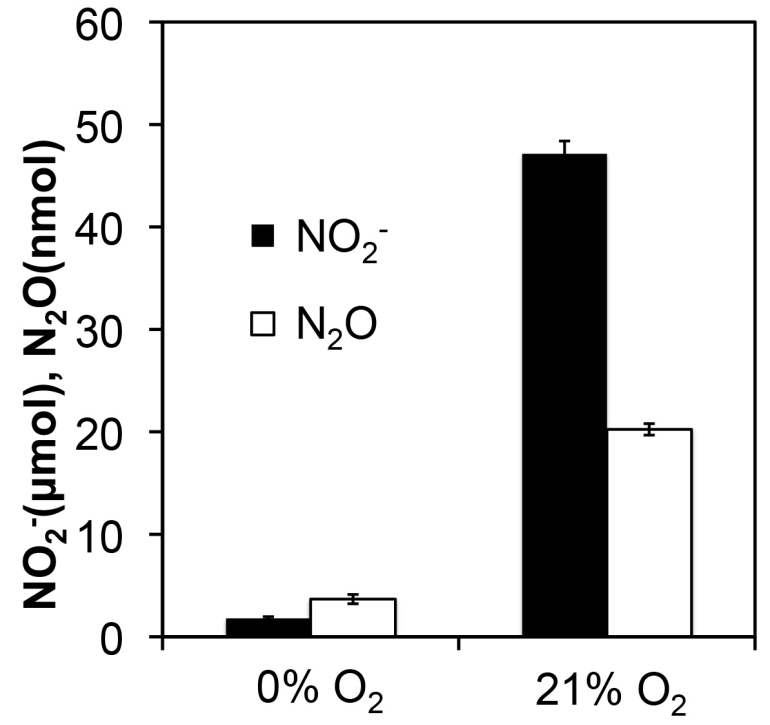

Figure 2. Amount of $\mathrm{NO}_{2}^{-}$and $\mathrm{N}_{2} \mathrm{O}$ produced from $378 \mu \mathrm{mol}$ of $\mathrm{NH}_{4}^{+}$in concentrated cell suspensions of $N$. oceani under different initial $\mathrm{O}_{2}$ concentrations $(n=2)$.

to initial $\mathrm{NH}_{2} \mathrm{OH}$ ), and it must have been produced by noncatalytic reactions.

The yield of $\mathrm{N}_{2} \mathrm{O}$ produced by the reduction of $\mathrm{NO}$ with NOR exceeded $100 \%$, which could be caused by underestimation of initial NO concentration. Since the NO-saturated ethanol solution was prepared by purging the ethanol with pure $\mathrm{NO}$ gas in a sealed vial at room temperature $\left(25^{\circ} \mathrm{C}\right)$, we calculated the NO concentration based on NO solubility at $25^{\circ} \mathrm{C}$ and $1 \mathrm{~atm}$. However, there is a possibility that the vial inside was pressurized and the excess $\mathrm{NO}$ dissolved in ethanol during the preservation at $4{ }^{\circ} \mathrm{C}$.

The SP value of $\mathrm{N}_{2} \mathrm{O}$ produced during the in vitro reduction of NO with NOR from P. denitirifcans $(-5.9 \pm 2.1 \%$ o $)$ agrees with the value reported for $\mathrm{N}_{2} \mathrm{O}$ produced in vivo from $\mathrm{NO}_{3}^{-}$reduction by the same species $(-5.1 \pm 1.8 \%$, Toyoda et al. 2005). Therefore, our results prove that the factorcontrolling $\mathrm{SP}$ value of $\mathrm{N}_{2} \mathrm{O}$ produced in $\mathrm{NO}_{3}^{-}$reduction is the reaction with NOR rather than other reaction steps, including diffusion of substrate and product through cell membranes. However, the SP value is slightly lower than SP values reported for $\mathrm{N}_{2} \mathrm{O}$ produced from $\mathrm{NO}_{3}^{-}$or $\mathrm{NO}_{2}^{-}$reduction by other denitrifying bacteria or some species of AOB ( -0.8 to $+0.1 \%$ ) (Sutka et al., 2004, 2006), and slightly higher than the value estimated for $\mathrm{N}_{2} \mathrm{O}$ produced from $\mathrm{NO}_{2}^{-}$reduction by $N$. marina $113 a$, oceanic AOB $(-10.7 \pm 2.9 \%$; Frame and Casciotti 2010). This implies that SP might depend on a small structural difference in the active center of NOR between the studied species, or that previously reported SP for $\mathrm{N}_{2} \mathrm{O}$ from $\mathrm{NO}_{3}^{-} / \mathrm{NO}_{2}^{-}$reduction could have been affected by other processes like $\mathrm{NH}_{2} \mathrm{OH}$ oxidation.

It is known that $\mathrm{AOB}$ produce $\mathrm{N}_{2} \mathrm{O}$ as a byproduct during the oxidation of $\mathrm{NH}_{2} \mathrm{OH}$ to $\mathrm{NO}_{2}^{-}$with $\mathrm{HAO}$ and that some species of $\mathrm{AOB}$ can also produce $\mathrm{N}_{2} \mathrm{O}$ from nitrite by the sequential reduction of nitrite to NO (using NIR) followed by reduction of NO (using NOR) (Klotz et al., 2006; Arp et al., 2003). The latter pathway is often referred to as nitrifierdenitrification (Wrage et al., 2001) and is believed to occur under anaerobic conditions. Although elucidating the reason why those AOB function as nitrifier-denitrification requires study of a wider spectrum of strains, detoxification of accumulated nitrite, co-respiration of oxygen and nitrite, and other mechanisms have been proposed (Beaumont et al., 2004; Stein, 2011).

In our bacterial culture experiments, production of both $\mathrm{NO}_{2}^{-}$and $\mathrm{N}_{2} \mathrm{O}$ are enhanced under aerobic conditions (Fig. 2) because $\mathrm{O}_{2}$ is required for ammonium oxidation, the first step of the successive reaction to $\mathrm{NO}_{2}^{-}$. Although we did not measure $\mathrm{O}_{2}$ concentration during the aerobic incubation $\left(21 \% \mathrm{O}_{2}\right)$, oxygen concentration must have been 


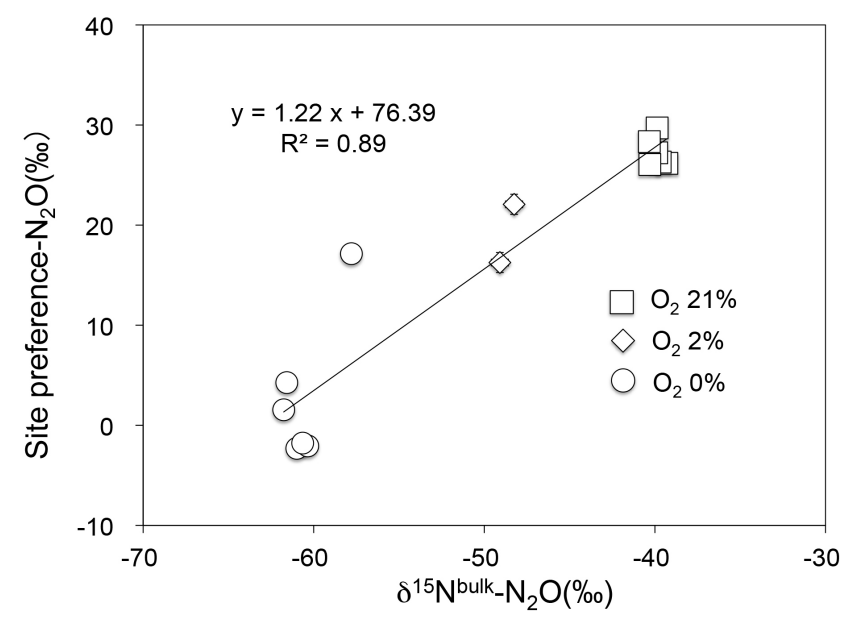

Figure 3. Site preference and $\delta^{15} \mathrm{~N}$ of $\mathrm{N}_{2} \mathrm{O}$ in concentrated cell suspensions of $N$. oceani under different initial $\mathrm{O}_{2}$ concentrations. Error bar indicates the measurement error.

kept high enough to maintain the aerobic condition for the following reasons: (1) it is reported that the measured ratio of consumed $\mathrm{O}_{2}$ and produced $\mathrm{NO}_{2}^{-}$during aerobic incubation of $N$. oceani $(1.35-1.43)$ is consistent with the ratio calculated from the stoichiometry of ammonia oxidation to nitrite (1.50) (Gundersen, 1966); (2) oxygen consumption by respiration using endogenous organics is low (Gundersen, 1966); and (3) a quantitative estimate based on the stoichiometry and the amount of the product $\left(\mathrm{NO}_{2}^{-}\right.$and $\left.\mathrm{N}_{2} \mathrm{O}\right)$ in this study indicates that the oxygen consumption was relatively small (e.g., oxygen concentration should have decreased from $21 \%$ to ca. $18 \%)$.

Furthermore, observed co-variation of SP values of $\mathrm{N}_{2} \mathrm{O}$ and oxygen concentrations (Fig. 3) implies that relative contributions from the two production pathways are sensitive to oxygen availability. It has been shown that $\mathrm{SP}$ of $\mathrm{N}_{2} \mathrm{O}$ produced by nitrifier-denitrification and by $\mathrm{NH}_{2} \mathrm{OH}$ oxidation are approximately 0 and $30 \%$, respectively (Sutka et al., 2006). Consequently, the lower SP values produced during nitrification in this study are most likely the result of the addition of $\mathrm{N}_{2} \mathrm{O}$ from nitrifier-denitrification. It turns out that $\mathrm{NH}_{2} \mathrm{OH}$ oxidation is the dominant $\mathrm{N}_{2} \mathrm{O}$ production pathway under aerobic conditions, while $\mathrm{NO}_{2}^{-}$reduction is dominant under anaerobic conditions (Fig. 3). We note that even in aerobic conditions $\left(21 \% \mathrm{O}_{2}\right)$, the $\mathrm{SP}$ value of $\mathrm{N}_{2} \mathrm{O}$ produced by $N$. oceani is lower than that of $\mathrm{N}_{2} \mathrm{O}$ produced by in vitro $\mathrm{NH}_{2} \mathrm{OH}$ oxidation with $\mathrm{HAO}$ extracted from the same bacteria (Fig. 3). This suggests the $\mathrm{NO}_{2}^{-}$reduction pathway is not negligible under aerobic conditions and thus previous studies based on pure culture incubation of $\mathrm{AOB}$ underestimated the $\mathrm{SP}$ value for $\mathrm{N}_{2} \mathrm{O}$ from $\mathrm{NH}_{2} \mathrm{OH}$ oxidation.

We further show quantitative estimation of the contribution of $\mathrm{NO}_{2}^{-}$reduction to $\mathrm{N}_{2} \mathrm{O}$ production. Here we assume that only $\mathrm{NH}_{2} \mathrm{OH}$ oxidation and nitrifier-denitrification were the $\mathrm{N}_{2} \mathrm{O}$ production pathways, although there was a possi- bility that $\mathrm{N}_{2} \mathrm{O}$ was produced by other unknown processes. This assumption allows a simple interpretation of the relative contribution of hydroxylamine oxidation and nitrifierdenitrification to $\mathrm{N}_{2} \mathrm{O}$ production on the basis of SP as follows.

$\mathrm{SP}_{\text {measured }}=\mathrm{SP}_{\mathrm{NOR}} \times X_{\mathrm{NOR}}+\mathrm{SP}_{\mathrm{HAO}} \times\left(1-X_{\mathrm{NOR}}\right)$

In Eq. (4), $\mathrm{SP}_{\text {measured }}, \mathrm{SP}_{\mathrm{NOR}}$, and $\mathrm{SP}_{\mathrm{HAO}}$ represent $\mathrm{SP}$ values of observed $\mathrm{N}_{2} \mathrm{O}$ and $\mathrm{N}_{2} \mathrm{O}$ produced in enzymatic reaction with NOR and HAO, respectively, and $X_{\mathrm{NOR}}$ indicates the relative contribution of the NOR-mediated pathway. As shown in Table 4, average $X_{\mathrm{NOR}}$ is calculated as $82 \pm 18 \%$, $42 \pm 10 \%$, and $22 \pm 4 \%$ under 0,2 , and $21 \%$ initial $\mathrm{O}_{2}$ concentrations, respectively. These values were similar to those measured by Frame and Casciotti (2010). Using the total amount of $\mathrm{N}_{2} \mathrm{O}$ produced in each experiment, the $\mathrm{N}_{2} \mathrm{O}$ produced from $\mathrm{NO}_{2}^{-}$reduction is estimated at $2.5 \pm 1.0 \mathrm{nmol}$ $(n=6), 3.8 \pm 0.7 \mathrm{nmol}(n=2), 3.9 \pm 0.7 \mathrm{nmol}(n=5)$ under 0,2 , and $21 \%$ initial $\mathrm{O}_{2}$ concentrations, respectively. This means that the rate of $\mathrm{N}_{2} \mathrm{O}$ production via the $\mathrm{NO}_{2}^{-}$ reduction pathway does not depend on the amount of $\mathrm{NO}_{2}^{-}$ produced, which showed an increase of more than 20 times under aerobic conditions compared to anaerobic conditions. This might indicate that activities of NIR or NOR were not enhanced in this study, although we did not directly measure the regulation and activity of the enzymes. The process information provided by SP values enables us to estimate bulk ${ }^{15} \mathrm{~N}$-enrichment factors $(\varepsilon$, which is approximately equal to $\delta^{15} \mathrm{~N}_{\text {product }}-\delta^{15} \mathrm{~N}_{\text {substrate }}$ under the excess supply of substrate) for $\mathrm{N}_{2} \mathrm{O}$ production from $\mathrm{NH}_{4}^{+}$by NORand $\mathrm{HAO}$-mediated pathways. If $\mathrm{N}_{2} \mathrm{O}$ is produced only by a $\mathrm{NH}_{2} \mathrm{OH}$ oxidation pathway $\left(X_{\mathrm{NOR}}=0\right), \mathrm{SP}_{\text {measured }}=\mathrm{SP}_{\mathrm{HAO}}$ and $\delta^{15} \mathrm{~N}^{\text {bulk }}$ of $\mathrm{N}_{2} \mathrm{O}$ is estimated at $-32.9 \%$ from the linear relationship between SP and $\delta^{15} \mathrm{~N}^{\text {bulk }}$ (Fig. 3). However, if $\mathrm{N}_{2} \mathrm{O}$ is produced only by a $\mathrm{NO}_{2}^{-}$reduction pathway $\left(X_{\mathrm{NOR}}=1\right), \mathrm{SP}_{\text {measured }}=\mathrm{SP}_{\mathrm{NOR}}$ and $\delta{ }^{15} \mathrm{~N}^{\text {bulk }}$ of $\mathrm{N}_{2} \mathrm{O}$ is estimated at $-67.5 \%$. Combining these values with $\delta^{15} \mathrm{~N}$ of $\left(\mathrm{NH}_{4}\right)_{2} \mathrm{SO}_{4}$ used in this study $(=-0.34 \%$ ) , we obtain $\varepsilon_{\mathrm{HAO}}=-32.6 \% \mathrm{o}$ and $\varepsilon_{\mathrm{NOR}}=-67.2 \%$. The $\varepsilon_{N O R}$ value is about $10 \%$ o lower than the value estimated from pure culture incubation of Nitrosomonas marina C-113a (Frame and Casciotti, 2010) under several $\mathrm{O}_{2}$ concentrations $\left({ }^{15} \varepsilon_{\mathrm{ND}}=-56.9 \%\right.$ o). The cause of the difference could be different experimental approaches (with/without enzymatic reactions) or different species studied. However, it is evident that $\varepsilon$ is significantly different between the $\mathrm{NH}_{2} \mathrm{OH}$ oxidation pathway and the $\mathrm{NO}_{2}^{-}$reduction pathway.

Finally, we discuss the mechanisms that control SP values of $\mathrm{N}_{2} \mathrm{O}$ produced during the enzymatic reactions. Both $\mathrm{HAO}$ and NOR enzymes are known to have Fe atoms as active centers, but their structures are different according to functional types. Because the catalytic site of $\mathrm{HAO}$ has a single $\mathrm{Fe}$ atom (one nuclear center) (Igarashi et al., 1997), it is likely that a single $\mathrm{NH}_{2} \mathrm{OH}$ molecule binds to the center and is oxidized 
Table 4. Estimated contribution of $\mathrm{NO}_{2}^{-}$reduction catalyzed by NOR to $\mathrm{N}_{2} \mathrm{O}$ production by $N$. oceani under different initial $\mathrm{O}_{2}$ concentrations.

\begin{tabular}{lllll}
\hline $\begin{array}{l}\text { Initial } \mathrm{O}_{2} \\
(\%)\end{array}$ & $\begin{array}{l}\mathrm{N}_{2} \mathrm{O} \\
(\mathrm{nmol})\end{array}$ & $\begin{array}{l}\mathrm{N}_{2} \mathrm{O} \text { yield } \\
\left(10^{-5}\right)\end{array}$ & $X_{\mathrm{NOR}^{*}}$ & $\begin{array}{l}\mathrm{N}_{2} \mathrm{O}_{\mathrm{NOR}}{ }^{* *} \\
(\mathrm{nmol})\end{array}$ \\
\hline $0 \%$ & $2.9 \pm 0.9$ & $1.5 \pm 0.5$ & $0.82 \pm 0.18$ & $2.5 \pm 1.0$ \\
$2 \%$ & $8.9 \pm 0.5$ & $4.7 \pm 0.3$ & $0.42 \pm 0.10$ & $3.8 \pm 0.7$ \\
$21 \%$ & $18.1 \pm 3.6$ & $9.5 \pm 1.9$ & $0.22 \pm 0.04$ & $3.9 \pm 0.7$ \\
\hline
\end{tabular}

$\mathrm{N}_{2} \mathrm{O}$ yield represents the fraction of $\mathrm{N}$ atoms converted to $\mathrm{N}_{2} \mathrm{O}$ from substrate $\mathrm{NH}_{4}^{+}$ $\left(\left[\mathrm{N}_{2} \mathrm{O}-\mathrm{N}\right] /\left[\mathrm{NH}_{4}^{+}-\mathrm{N}\right]\right)$.

* Contribution of $\mathrm{NO}_{2}^{-}$reduction to $\mathrm{N}_{2} \mathrm{O}$ production.

** Amount of $\mathrm{N}_{2} \mathrm{O}$ produced by $\mathrm{NO}_{2}^{-}$reduction.

to $\mathrm{NO}_{2}^{-}$. To explain the high $\mathrm{SP}$ values of the $\mathrm{N}_{2} \mathrm{O}$ generated by HAO reactions, we propose a two-step reaction mechanism as indicated in Fig. 4.

If substrate $\mathrm{NH}_{2} \mathrm{OH}$ is supplied in excess or the electron acceptor for the reaction is lacking, however, another $\mathrm{NH}_{2} \mathrm{OH}$ molecule will bind to the same center to form an $\mathrm{N}$ $\mathrm{N}$ bond. In this case, the primary-binding $\mathrm{NH}_{2} \mathrm{OH}$ molecule could be more depleted in ${ }^{15} \mathrm{~N}$ than the secondary-binding $\mathrm{NH}_{2} \mathrm{OH}$ molecule by the kinetic isotope effect. The observed positive SP might indicate that the peripheral $(\beta)$ and central $(\alpha) \mathrm{N}$ atoms in the product $\mathrm{N}_{2} \mathrm{O}$ derive from the primary and secondary $\mathrm{NH}_{2} \mathrm{OH}$, respectively.

The catalytic center of the $N$. europaea HAO for hydroxylamine oxidation is formed by the P460 molecule and the side-chains of three amino acids (Asp291, His292, Tyr358; $N$. europaea HAO numbering) that surround the distal side of the heme (Igarashi et al. 1996). Although two of the three residues (Asp291 and His292) are completely conserved among all the HAOs, the other (Tyr358) is replaced by Asn in the enzymes of the gamma-AOBs, including the NS58. Recently, the crystal structure of the $N$. europaea $\mathrm{HAO}$ in the substrate-binding state was reported by Maalcke et al. (2014). They proposed that the side-chain of Tyr358 would participate in the second step of the two-step reaction shown in Fig. 4, namely the addition of water molecules to the intermediate species bound on the $\mathrm{P} 460$. The replacement of the Tyr to Asn in N. oceani NS58 HAO (Asn368) may obstruct the addition of $\mathrm{H}_{2} \mathrm{O}$ to the intermediate in the $\mathrm{HAO}$ reaction. For that reason, it is probable that the $\mathrm{N}_{2} \mathrm{O}$-generating pathway shown in the Fig. 4 would be more likely to occur in the case of $N$. oceani NS58 HAO compared to the case of $N$. europaea HAO. In addition, this explanation is consistent with the present result that $N$. oceani NS58 generates more $\mathrm{N}_{2} \mathrm{O}$ under the aerobic condition than the anaerobic condition (Fig 3), showing a contrast to the case of N. europaea (Poth and Focht., 1985).

In the case of NOR, three types are known for bacteria: cNOR that accepts electrons from cytochrome c, and qNOR and qCuNOR that accept electrons from quinols (Zumft et al. 2005). Bacterial denitrification is considered to be catalyzed

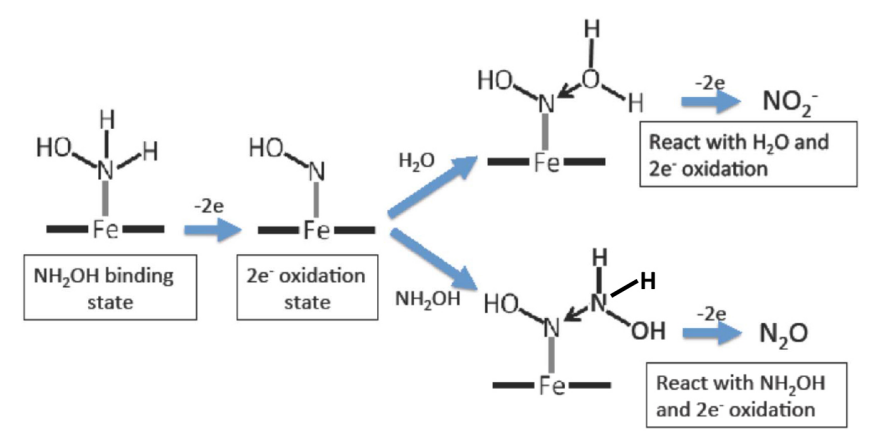

Figure 4. Two-step model of $\mathrm{NH}_{2} \mathrm{OH}$ oxidation catalyzed by $\mathrm{HAO}$.

by cNOR, although qNOR and qCuNOR may be responsible for detoxification of NO produced in environments (Hendriks et al. 2000). The active site of NOR enzymes has two Fe atoms (binuclear center) and have similarity among NOR types. In the case of cNOR, the binuclear center consists of non-heme iron $\left(\mathrm{Fe}_{\mathrm{b}}\right)$ and heme $\mathrm{b}_{3}$ (Hino et al. 2010), and it is proposed that two NO molecules respectively bind to the two centers simultaneously to form $\mathrm{N}_{2} \mathrm{O}$ (Watmough et al. 2009). This parallel binding mechanism could bring about nearly the same isotope effect for the two $\mathrm{N}$ atoms in intermediate $\mathrm{ONNO}$, and if the elimination of the $\mathrm{O}$ atom from $\mathrm{N}-\mathrm{O}$ bonding does not fractionate ${ }^{15} \mathrm{~N}$ within the intermediate molecule, then the $\mathrm{SP}$ value of $\mathrm{N}_{2} \mathrm{O}$ would be nearly $0 \%$.

\section{Conclusions}

We presented direct evidence that SP values of $\mathrm{N}_{2} \mathrm{O}$ produced by bacterial nitrification and denitrification are controlled by the enzymatic reactions of HAO and NOR during $\mathrm{NH}_{2} \mathrm{OH}$ oxidation and $\mathrm{NO}$ reduction, respectively. The SP value does not depend on factors like concentration and isotope ratios of substrate and degree of reaction progress. Using the distinct SP values for HAO- and NOR-related processes, we evaluated the relative contributions from the two pathways of $\mathrm{N}_{2} \mathrm{O}$ production by $\mathrm{AOB}$ in pure culture, and showed that they are sensitive to oxygen concentration and that $\mathrm{NO}_{2}^{-}$reduction could occur under aerobic conditions.

Although further studies are required, this study demonstrates that isotopomer analysis constitutes a powerful tool to investigate $\mathrm{N}_{2} \mathrm{O}$ production pathways in various environments. It will be important to expand these observations beyond nitrifying and denitrifying bacteria to examine the generality of these results. For example, isotopomeric characteristics on fungal denitrification and archaeal nitrification have been reported only recently (Santro et al., 2011; Sutka et al., 2008), and those on fungal co-denitrification are unknown. Combined analysis of several isotopomer ratios should be developed to distinguish $\mathrm{NH}_{2} \mathrm{OH}$ oxidation and fungal denitrification, because SP values of $\mathrm{N}_{2} \mathrm{O}$ from the two pathways have been found to be nearly the same (Sutka et al., 
2008). As for the characterization of various microbial $\mathrm{N}_{2} \mathrm{O}$ production processes, studies focused on enzymatic reactions would be effective, as shown in this work. Although the enzymatic pathway for $\mathrm{N}_{2} \mathrm{O}$ production by AOA is still uncertain, combined analysis of genome sequences, physiology, and isotopomer ratios would promise further understanding of microbial $\mathrm{N}_{2} \mathrm{O}$ production mechanisms.

\section{The Supplement related to this article is available online at doi:10.5194/bg-11-2679-2014-supplement.}

Acknowledgements. We thank members of Yoshida Laboratory at Tokyo Tech for fruitful discussions and kind technical assistance. F. Breider is acknowledged for proofreading of the manuscript. This work was supported by the Global Environmental Research Fund (A-0904) of the Ministry of the Environment, Japan, and by KAKENHI (23224013 and 25340006) of the Ministry of Education, Culture, Sports, Science and Technology, Japan.

Edited by: J. Middelburg

\section{References}

Arp, D. J. and Stein, L. Y.: Metabolism of inorganic N compounds by ammonia-oxidizing bacteria, Crit. Rev. Biochem. Mol. Biol., 38, 471-495, 2003.

Baggs, E. M.: A review of stable isotope techniques for $\mathrm{N}_{2} \mathrm{O}$ source partitioning in soils: recent progress, remaining challenges and future considerations, Rapid Commun. Mass. Sp., 22, 1664 1672, 2008.

Beaumont, H. J., Lens, S. I., Reijnders, W., Westerhoff, H. V., and van Spanning, R. J.: Expression of nitrite reductase in Nitrosomonas europaea involves NsrR, a novel nitritesensitive transcription repressor, Mol. Microbiol., 54, 148-158, doi:10.1111/j.1365-2958.2004.04248.x, 2004.

Casciotti, K., Buchwald, C., Santoro, A. E., and Frame, C.: Assessment of nitrogen and oxygen isotopic fractionation during nitrification and itsexpression in the marine environment, Methods Enzymol., 486, 253-280, doi:10.1016/B978-0-12-381294-0.00011$0,2011$.

Frame, C. H. and Casciotti, K. L.: Biogeochemical controls and isotopic signatures of nitrous oxide production by a marine ammonia-oxidizing bacterium, Biogeosciences, 7, 2695-2709, doi:10.5194/bgd-7-3019-2010, 2010.

Fujiwara, T. and Fukumori, Y.: Cytochrome $c b$-type nitric oxide reductase with cytochrome $c$ oxidase activity from Paracoccus denitrificans ATCC 35512, J. Bacteriol., 178, 1866-1871, 1996.

Goldberg, S. D., Borken, W., and Gebauer, G.: $\mathrm{N}_{2} \mathrm{O}$ emission in a Norway spruce forest due to soil frost: concentration and isotope profiles shed a new light on an old story, Biochem., 97, 21-30, doi:10.1007/s10533-009-9294-z, 2010.

Gundersen, K.: The growth and respiration of Nitrosocystis oceanus at different partial pressures of oxygen, J. Gen. Microbiol., 42, 387-396, 1966.
Hayatu, M., Tago, K., and Saito, M.: Various players in the nitrogen cycle; Diversity and functions of the microorganisms involved in nitrification and denitrification, Soil Sci. Plant Nutri., 54, 33-45, doi:10.1111/j.1747-0765.2007.00195.x, 2008.

Hino, T., Matsumoto, Y., Nagano, S., Sugimoto, H., Fukumori, Y., Murata, T., Iwata, S., and Shiro, Y.: Structural Basis of Biological $\mathrm{N}_{2} \mathrm{O}$ Generation by Bacterial Nitric Oxide Reductase, Science, 330, 1666, doi:10.1126/science.1195591, 2010.

Hendriks. J., Oubrie, A., Castresana, J., Urbani, A., Gemeinhardt, S., and Saraste, M.: Nitric oxide reductases in bacteria, Biochim. Biophys. Ac., 1459, 266-273, 2000.

Hozuki, T., Ohtsuka, T., Arai, K., Yoshimatsu, K., Tanaka, S., and Fujiwara, T.: Effect of salinity on hydroxylamineoxidation in marine ammonia-oxidizing $\gamma$-proteobacterium, Nitrosococcus oceani: molecular and catalytic properties of tetraheme cytochrome $c$-554, Microbes Environ., 25, 95-102, doi:10.1264/jsme2.ME09154, 2010.

Igarashi, N., Moriyama, H., Fujiwara, T., Fukumori, Y., and Tanaka, N.: The $2.8 \AA$ structure of hydroxylamine oxidoreductase from a nitrifying chemoautotrophic bacterium, Nitrosomonas europaea, Nat. Struct. Biol., 4, 276-284, doi:10.1038/nsb0497-276, 1997.

Koba, K., Osaka, K., Tobari, Y., Toyoda, S., Ohte, N., Katsuyama, M., Suzuki, N., Itoh, M., Yamagishi, H., Kawasaki, M., Kim, S. J., Yoshida, N., and Nakajima, T.: Biogeochemistry of nitrous oxide in groundwater in a forested ecosystem elucidated by nitrous oxide isotopomer measurements, Geochim. Cosmochim. Ac., 73, 3115-3133, doi:10.1016/j.gca.2009.03.022, 2009.

Klotz, M. G., Arp, D. J., Chain, P. S. G., El-Sheikh, A. F., Hauser, L. J., Hommes, N. G., Larimer, F. W., Malfatti, S. A., Norton, J. M., Poret-Peterson, A. T., Vergez, L. M., and Ward, B. B.: Complete genome sequence of the marine, chemolithoautotrophic, ammonia-oxidizing bacterium Nitrosococcus oceani ATCC 19707, Appl. Environ. Microbiol., 72, 6299-6315, doi:10.1128/AEM.00463-06, 2006.

Maalcke, W. J., Dietl, A., Marritt, S. J., Butt, J. N., Jetten, M. S. M., Keltjens, J. T., Barends, T. R. M., and Kartal, B.: Structural basis of biological NO generation by octaheme oxidoreductases, J. Biol. Chem., 289, 1228-1242, doi:10.1074/jbc.M113.525147, 2014.

Nicholas, D. J. D. and Mason, A.: Determination of nitrate and nitrite, Methods Enzymol., 3, 981-984, 1957.

Numata, M., Saito, T., Yamazaki,T., Fukumori, Y., and Yamanaka, T.: Cytochrome P-460 of Nitrosomonas europaea: further purification and further characterization., J. Biochem., 108, 10161023, 1990.

Park, S., Pérez, T., Boering, K. A., Trumbore, S. E., Gil, J., Marquina, S., and Tyler, S. C.: Can $\mathrm{N}_{2} \mathrm{O}$ stable isotopes and isotopomers be useful tools to characterize sources and microbial pathways of $\mathrm{N}_{2} \mathrm{O}$ production and consumption in tropical soils?, Global Biogeochem. Cy., 25, GB1001, doi:10.1029/2009GB003615, 2011.

Poth, M. and Focht, D.: ${ }^{15} \mathrm{~N}$ kinetic analysis of $\mathrm{N}_{2} \mathrm{O}$ production by Nitrosomonas europaea: an examination of nitrifier denitrification, Appl. Environ. Microbiol., 49, 1134-1141, 1985.

Ravishankara, A. R., Daniel, J., and Sortman, R. W.: Nitrous oxide $\left(\mathrm{N}_{2} \mathrm{O}\right)$ : The dominant ozone-depleting substance emitted in the $21^{\text {st }}$ century, Science, 326, 123-125, doi:10.1126/science.1176985, 2009. 
Santoro, A. E., Buchwald, C., McIlvin, M. R., and Casciotti, K. L.: Isotopic signature of $\mathrm{N}_{2} \mathrm{O}$ produced by marine ammonia-oxidizing archaea, Science, 333, 1282-1285, doi:10.1126/science.1208239, 2011.

Sasaki, Y., Koba, K., Yamamoto, M., Makabe, A., Ueno, Y., Nakagawa, M., Toyoda, S., Yoshida, N., and Yoh, M.: Biogeochemistry of nitrous oxide in Lake Kizaki, Japan, elucidated by nitrous oxide isotopomer analysis, J. Geophys. Res., 116, G04030, doi:10.1029/2010JG001589, 2011.

Seidell, A. and Linke, W. F.: Solubilities of inorganic and metal organic compounds, 4th Ed., American Chemical Society, Washington DC, 792 pp., 1965.

Stein, L. Y.: Heterotrophic nitrification and nitrifier denitrification, in: Nitrification, edited by: Ward, B. B., Klotz, M. G., and Arp, D. A., ASM Press, Washington DC, 95-114, 2011.

Stein, L. Y. and Yung, Y. L.: Production, Isotopic composition, and Atmospheric fate of biologically produced nitrous oxide, Annu. Rev. Earth Planet Sci., 31, 329-56, doi:10.1146/annurev.earth.31.110502.080901, 2003.

Sutka, R. L., Ostrom, N. E., Ostrom, P. H., Gandhi, H., and Breznak, J. A.: Nitrogen isotopomer site preference of $\mathrm{N}_{2} \mathrm{O}$ produced by Nitrosomonas europaea and Methylococcuscapsulatus Bath, Rapid Commun. Mass Sp., 17, 738-745, doi:10.1002/rcm.968, 2003.

Sutka, R. L., Ostrom, N. E., Ostrom, P. H., Gandhi, H., and Breznak, J. A.: Erratum Nitrogen isotopomer site preference of $\mathrm{N}_{2} \mathrm{O}$ produced by Nitrosomonas europaea and Methylococcuscapsulatus Bath, Rapid Commun. Mass Sp., 18, 1411-1412, doi:10.1002/rcm.1482, 2004.

Sutka, R. L., Ostrom, N. E., Ostrom, P. H., Breznak, J. A., Pitt, A. J., Li, F., and Gandhi, H.: Distinguishing Nitrous Oxide Production from Nitrification and Denitrification on the Basis of Isotopomer Abundances, Appl. Environ. Microbiol., 638-644, doi:10.1128/AEM.72.1.638-644.2006, 2006.

Sutka, R. L., Adams, G. C., Ostrom, N. E., and Ostrom, P. E.: Isotopologue fractionation during $\mathrm{N}_{2} \mathrm{O}$ production by fungal denitrification, Rapid Commun. Mass Sp., 22, 3986-3996, doi:10.1002/rcm.3820, 2008.

Takenaka, T., Tashiro, T., Ozaki, A., Takakubo, H., Yamamoto, Y., Maruyama, T., Nagaosa, K., Kimura, H., and Kato, K.: Planktonic bacterial population dynamics with environmental changes in coastal areas of Suruga Bay, Microbes Environ., 22, 257-267, doi:10.1264/jsme2.22.257, 2007.

Terry, K. R. and Hooper, A. B.: Hydroxylamine oxidoreductase: a 20-heme, 200,000 molecular weight cytochrome c with unusual denaturation properties which forms a 63,000 molecular weight monomer after heme removal, Biochem., 20, 7026-7032, doi:10.1021/bi00527a039, 1981.
Toyoda, S. and Yoshida, N.: Determination of nitrogen isotopomers of nitrous oxide on a modified isotope ratio mass spectrometer, Anal. Chem., 71, 4711-4718, doi:10.1021/ac9904563, 1999.

Toyoda, S., Yoshida, N., Miwa, T., Matsui, Y, Yamagishi, H., and Tsunogai, U.: Production mechanism and global budget of $\mathrm{N}_{2} \mathrm{O}$ inferred from its isotopomers in the western North Pacific, Geophys. Res. Lett., 29, doi:10.1029/2001GL014311, 2002.

Toyoda, S., Mutobe, H., Yamagishi, H., Yoshida, N., and Tanji, Y.: Fractionation of $\mathrm{N}_{2} \mathrm{O}$ isotopomers during production by denitrifier, Soil. Biol. Biochem., 37, 1535-1545, doi:10.1016/j.soilbio.2005.01.009, 2005.

Toyoda, S., Suzuki, Y., Hattori, S., Yamada, K., Fujii, A., Yoshida, N., Kouno, R., Murayama, K., and Shiomi, H.: Isotopomer analysis of production and consumption mechanisms of $\mathrm{N}_{2} \mathrm{O}$ and $\mathrm{CH}_{4}$ in an advanced wastewater treatment system, Environ. Sci. Technol., 45, 917-922, doi:10.1021/es102985u, 2011.

Watmough, N. J., Field, S. J., Hughes, R. J. L., and Richardson, D. J.: The bacterial respiratory nitric oxide reductase, Biochem. Soc. T., 37, 392-399, doi:10.1042/BST0370392, 2009.

Well, R., Flessa, H., Xing, L., Xiaotang, J., and Romheld, $\mathrm{V}$.: Isotopologue ratios of $\mathrm{N}_{2} \mathrm{O}$ emitted from microcosms with $\mathrm{NH}_{4}^{+}$fertilized arable soils under conditions favoring nitrification, Soil Biol. Biochem., 40, 2416-2426, doi:10.1016/j.soilbio.2008.06.003, 2008.

Wrage, N., Velthof, G. L., van Beusichema, M. L., and Oenema, O.: Role of nitrifier denitrification in the production of nitrous oxide, Soil Biol. Biochem., 33, 1723-1732, 2001.

Yamanaka, T. and Sakano, Y.: Oxidation of hydroxylamine to nitrite catalyzed by hydroxylamine oxidoreductase purified from Nitrosomonas europaea, Curr. Microbiol., 4, 239-244, 1980.

Yamanaka, T. and Shinra, M.: Cytochrome $c-552$ and cytochrome $c$-554 derived from Nitrosomonas europaea. Purification, properties, and their function in hydroxylamine oxidation, J. Biochem., 75, 1265-1273, 1974.

Yamanaka, T., Shinra, M., Takahashi, K., and Shibasaka, M.: Highly purified hydroxylamine oxidoreductase from Nitrosomonas europaea: some physicochemical and enzymatic properties, J. Biochem., 86, 1101-1108, 1979.

Yoshida, $\mathrm{N} .:{ }^{15} \mathrm{~N}$ depleted $\mathrm{N}_{2} \mathrm{O}$ as a product of nitrification, Nature, 335, 528-529, 1988.

Yoshida, N. and Toyoda, S.: Constraining the atmospheric $\mathrm{N}_{2} \mathrm{O}$ budget from intramolecular site preference in $\mathrm{N}_{2} \mathrm{O}$ isotopomers, Nature, 405, 330-334, doi:10.1038/35012558, 2000.

Zumft, W. G.: Nitric oxide reductases of prokaryotes with emphasis on the respiratory, heme-copper oxidase type, J. Inorg Biochem., 99, 194-215, doi:10.1016/j.jinorgbio.2004.09.024, 2005. 